\title{
Movements of small adult black rockfish: implications for the design of MPAs
}

\author{
Kristen M. Green ${ }^{1,2,3, *}$, Richard M. Starr ${ }^{1,2}$ \\ ${ }^{1}$ Moss Landing Marine Laboratories, and ${ }^{2}$ University of California Sea Grant Extension Program, 8272 Moss Landing Road, \\ Moss Landing, California 95039, USA \\ ${ }^{3}$ Present address: Alaska Department of Fish and Game, 304 Lake Street, Room 103, Sitka, Alaska 99835, USA
}

\begin{abstract}
Off the coast of central California, USA, small black rockfish Sebastes melanops (individuals below the length at $50 \%$ maturity) comprise a large percentage of the catch in recreational fisheries, yet little is known about the movements of these small fish. To better understand their movements, we implanted acoustic transmitters into 23 black rockfish $(29$ to $41 \mathrm{~cm}$ total length) in Carmel Bay, California, USA. Tagged fish were monitored over a 16 mo period between August 2006 and January 2008. Their vertical movements were correlated with environmental variables such as atmospheric pressure, wind speed, upwelling, and wave height. From October to May, black rockfish moved to deeper waters offshore during the day and returned at night. In the summer, diurnal movements of black rockfish decreased in frequency, perhaps due to locally abundant food resources associated with seasonal upwelling. About two-thirds of the tagged black rockfish (14 fish) displayed a high degree of residency to the study area (>11 mo). The remaining third ( 9 fish) left the study area within 6 mo of release; signals from 4 of these fish were later detected on other acoustic receiver arrays $>50 \mathrm{~km}$ north of Carmel Bay. Storms may have caused those fish to move northward in winter. When in residence, the mean home range of tagged fish was $0.25 \mathrm{~km}^{2}$. Our results indicate that a better understanding of the variability of fish movements among age classes is necessary to design marine protected areas (MPAs) that are intended to protect all life stages of a species.
\end{abstract}

KEY WORDS: Acoustic telemetry - Sebastes melanops - MPA - Central California - Residency · Home range $\cdot$ Movements $\cdot$ Migration

\section{INTRODUCTION}

Resource managers are increasingly using marine protected areas (MPAs) to supplement existing fisheries management strategies. The reduction of fishing pressure within no-take MPAs has been shown to increase the numbers and sizes of fishes within reserve boundaries (Halpern \& Warner 2002, Micheli et al. 2004), and may enhance fisheries yields via movements of fishes to areas outside reserve boundaries (Starr et al. 2004, Russ et al. 2005, White et al. 2008). The conservation benefits afforded by no-take
MPAs, however, are primarily accrued for fish that stay within reserve boundaries, i.e. fishes with home ranges that are smaller than the reserve. To date, most information used to design MPAs has been based on the net movements of adult fishes, and has been derived from tag-recapture studies. Without information about daily and seasonal movements of immature as well as mature fishes, it is difficult to evaluate the performance of a MPA in achieving an expected level of protection (Botsford et al. 2008).

Historically, the black rockfish Sebastes melanops has been described as a species with strong site 
fidelity, and is typically managed as part of a complex of nearshore, residential rockfishes Sebastes spp. that may benefit from MPAs. Estimates of movements of adult black rockfish have been based primarily on tag-recapture studies, which have shown net movements of about $5 \mathrm{~km}$, with about $10 \%$ of tagged fish exhibiting greater (up to $600 \mathrm{~km}$ ) movements (Coombs 1979, DeMott 1983, Mathews \& Barker 1983, Culver 1986, Starr \& Green 2007). Tagrecapture studies, however, provide estimates of net movements only and do not account for short-term (e.g. daily) movements; this lack of temporal resolution about movements creates uncertainty with respect to MPA benefits. If black rockfish demonstrate strong site fidelity throughout their life, then MPA benefits would be greater than if movements of black rockfish vary with life stage.

Parker et al. (2007) represents the only published study that provides information about the daily and seasonal movements of black rockfish. They used acoustic telemetry techniques to provide information about the home ranges and vertical movements of adult black rockfish off Oregon, USA. However, in California, adult black rockfish are uncommon in the recreational catch (Mason 1998, O'Farrell \& Botsford 2006), and individuals in central California above the length at $50 \%$ maturity typically represent $<5 \%$ of the recreational catch (Starr \& Green 2007). To provide information about the movement patterns of smaller size-classes of black rockfish, we conducted a study to track the movements of small adult black rockfish using acoustic telemetry techniques in Carmel Bay, California, USA. The specific objectives of the present study were to: (1) describe the daily and seasonal movement patterns of small adult black rockfish and (2) quantify the home range and residence times of small adult black rockfish.

\section{MATERIALS AND METHODS}

\section{Study site}

We tagged black rockfish Sebastes melanops in a $4 \times 2 \mathrm{~km}$ area located within Carmel Bay, California (Fig. 1). Benthic habitats in Carmel Bay include high-relief rock areas and sand flats mixed with occasional low rocks. The high-relief areas are comprised of large boulders and rock outcrops up to $5 \mathrm{~m}$ in height. Sand flats gently slope to deeper waters, and the sand areas scattered rocks contain rocks or boulders with from 1 to $2 \mathrm{~m}$ in size. Seasonal beds of canopy-forming kelp Macrocystis

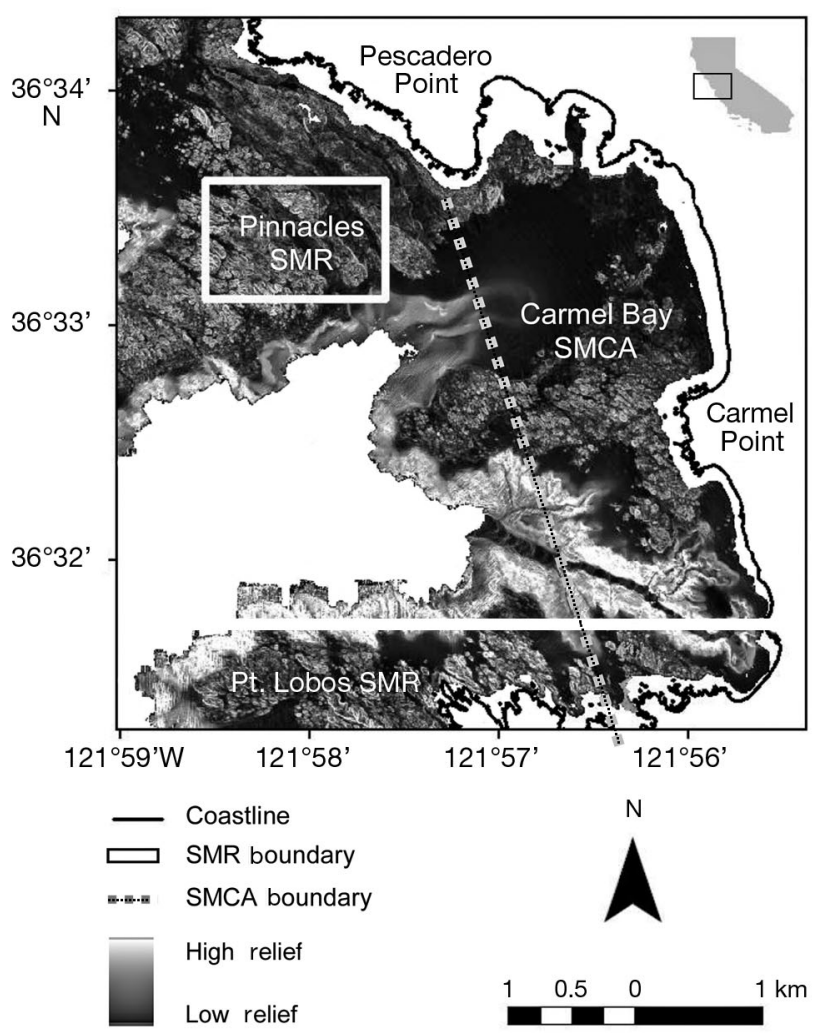

Fig. 1. Carmel Bay, Central California. Multibeam bathymetry imagery with Marine Protected Area boundaries. SMCA: State Marine Conservation Area; SMR: State Marine Reserve (data from the Seafloor Mapping Laboratory, California State University of Monterey Bay)

pyrifera and Nereocystis luetkeana, and perennial understory algae Pterygophera californica are abundant in the rocky habitats. The majority of the study area is within the boundaries of several MPAs (Fig. 1). The Carmel Bay State Marine Conservation Area (SMCA) allows recreational fishing but prohibits commercial fishing. The Carmel Pinnacles State Marine Reserve (SMR) and the Pt. Lobos SMR prohibit take of all marine species.

\section{Fishing, tagging, and data collection}

We caught black rockfish with rod and reel fishing gear during the fall of 2006 and summer of 2007 and tagged individuals that were between the mean length at first maturity $(25.0 \mathrm{~cm})$ and mean length at $50 \%$ maturity $(41.0 \mathrm{~cm}$ for females and $36.0 \mathrm{~cm}$ for males), as described by Wyllie Echeverria (1987). Thus, tagged fish were either large immature juveniles or small mature adults. For the 
present study, we termed these fish 'small adults,' because we could not determine maturity in the field. The sex of each fish was determined by the presence or absence of external papillae. Captured black rockfish were anesthetized by placing them in a solution $\left(0.1 \mathrm{~g} \mathrm{l}^{-1}\right)$ of tricaine methanosulfate (MS222). In 7 fish, we surgically implanted Vemco V13-1H-S256 acoustic transmitters (Vemco Ltd.) into the peritoneal cavity. In 16 fish, we implanted Vemco V13P-1H-S256 acoustic transmitters that contained pressure sensors as well. Transmitters emitted coded signals at a random interval between 90 and 270 s. Predicted battery life for each tag was $445 \mathrm{~d}$. An external T-bar anchor tag imprinted with a unique tag identification number was also implanted into the dorsal musculature of the fish in case of angler recapture. Fish were released at the location of capture.

We placed 31 acoustic receivers (Vemco VR-2 omni-directional acoustic monitors) along the coastline between Pescadero Point and Carmel Point, at depths from 7 to $40 \mathrm{~m}$ (Fig. 1). Receivers were individually anchored to a $40 \mathrm{~kg}$ mooring weight using a line that extended $\sim 5 \mathrm{~m}$ above the sea floor. A subsurface float was attached on a line above the receiver to maintain line tension and keep the receiver upright in the water column. Range tests indicated that the receiving range of moored receivers was $\sim 150 \mathrm{~m}$ (Greenley 2009). Temperature loggers (Onset StowAway Tidbit Underwater Data Loggers, programmed to record water temperature every $15 \mathrm{~min}$ ) were attached on the mooring line of 4 receivers. Each receiver had 3 temperature loggers, positioned at a shallow (12 to $16 \mathrm{~m}$ ), mid (18 to $24 \mathrm{~m}$ ), and deep (26 to $34 \mathrm{~m}$ ) depth interval. Data from moored receivers and temperature loggers were downloaded every 4 to 6 mo between August 2006 and January 2008.

Oceanographic and atmospheric data were acquired from the historical data archives of the $\mathrm{Na}$ tional Oceanic Atmospheric and Administration (NOAA). Wave height (m), wind speed, and barometric pressure $(\mathrm{mb})$ were recorded from Monterey Buoy 46042 (www.ndbc.noaa.gov). Tidal height (m) was recorded from Monterey Tide Station 9413450 (http://tidesonline.nos.noaa.gov/). Day lengths were derived from the historical archives of the US Naval Observatory from Carmel, California (http://aa.usno. navy.mil/data/). Daily and monthly upwelling indices, expressed as $\mathrm{m}^{3} \mathrm{~s}^{-1}$ per $100 \mathrm{~m}$ of coastline at $36^{\circ} \mathrm{N}, 122^{\circ} \mathrm{W}$ were obtained from NOAA Fisheries Pacific Fisheries Environmental Laboratory (PFEL) (www.pfeg.noaa.gov/products/PFEL).

\section{Data analyses}

Residence time for all tagged black rockfish, except fish carrying Tag 228, was calculated by dividing the total number of days a fish was present in the array by the predicted battery life of the transmitter. Daily presence in the array was defined as $\geq 2$ signal detections in a $24 \mathrm{~h}$ period. Residence time for fish carrying Tag 228 (recovered in the recreational fishery) was reported as a ratio of the days present in the study area to the number of days from release to recapture. The percentage of days each fish was absent from the array was calculated as the number of days absent divided by the number of days from release to the day the last tag transmission was recorded. Occasionally, receivers were temporarily missing from the array because they were moved or lost in storm events. For both residence time and absence calculations for a given fish, we excluded the dates from analyses for which a receiver was missing due to storms, if the lost receiver was the primary receiver that recorded signals from that tagged fish. By removing these dates and locations from analyses, we avoided reporting false absences for a tagged fish.

Diel changes in presence of black rockfish were characterized by calculating the percentage of hours a fish was detected in the study area during the day versus at night. Day hours were defined as the time period between sunrise and sunset. Night periods were defined as the time from $1 \mathrm{~h}$ after sunset until $1 \mathrm{~h}$ before sunrise. Crepuscular hours ( $1 \mathrm{~h}$ before sunrise and $1 \mathrm{~h}$ after sunset) were excluded from analyses. A fish was considered to be present in an hour if there was $\geq 1$ tag detection in that hour. The amount of time (hours) a tag was detected during the day or night on each date was normalized by the total night or day hours available on that date and summed to create a contingency table with the expected and observed percentage of hours detected for night periods versus day periods. Fisher's exact test was used to test the null hypothesis that there was no difference in fish presence in the study area, either between day and night periods annually or for selected seasons.

Vertical movements of black rockfish were examined by comparing differences in depth anomalies of tagged fish. To calculate daily depth anomalies, we subtracted the mean depth of a given fish on each date of the study from the annual mean depth for that fish. Depth anomalies were averaged across all fish on each date of the study to obtain a mean anomaly for each day and for day and night periods. Mean day 

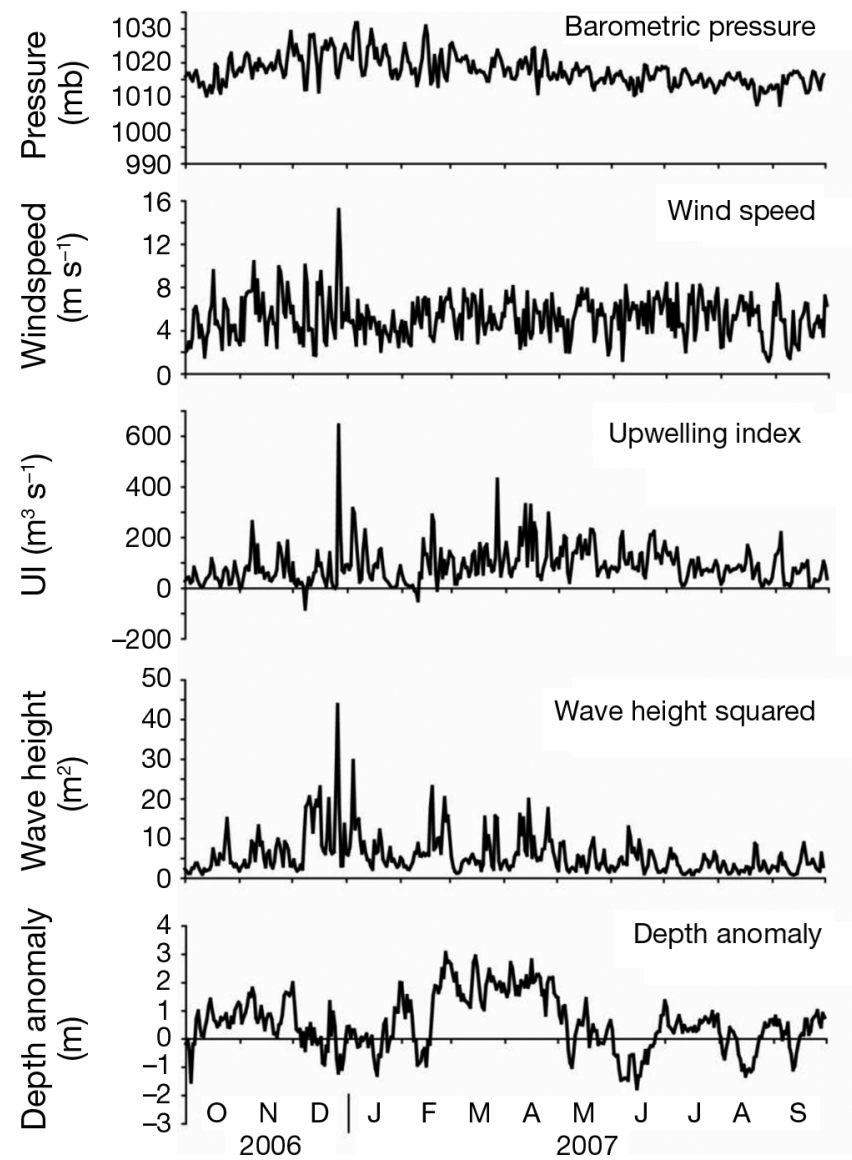

Fig. 2. Plots of mean daily barometric pressure, wind speed, upwelling index (per $100 \mathrm{~m}$ of coastline), mean wave height (squared), and depth anomalies of tagged black rockfish Sebastes melanops in or near the study area in Carmel Bay, CA. See 'Study site' for sources of data. A daily depth anomaly was obtained by subtracting the mean depth of a fish in a day from that individual's annual mean depth. Positive (negative) anomalies represent deeper (shallower) mean depth than the annual mean depth

depths were compared to mean night depths using $t$-tests.

We used cross correlation analysis to compare daily depth anomalies of black rockfish with daily water temperatures, tidal stages, the square of mean wave heights, wind speeds, upwelling indices, and barometric pressures (Fig. 2). We removed the effect of autocorrelation before computing the cross correlations, as suggested by Katz (1988). Serial correlation was excluded by fitting univariate models to the $\mathrm{X}$ and $\mathrm{Y}$ time series, using these fitted models to obtain estimated residuals, and then determining the cross correlation function between the 2 residual time series. We conducted the cross correlation analysis for 3 time periods: the entire study period, the high upwelling season (April to June), and the low up-

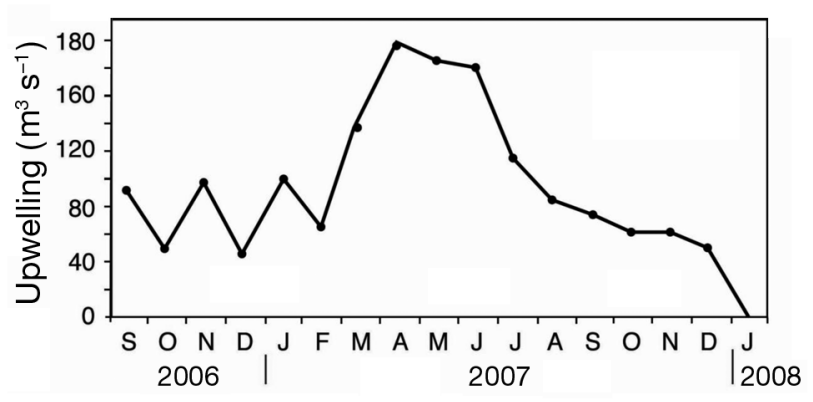

Fig. 3. Monthly upwelling index (per $100 \mathrm{~m}$ of coastline) at $36^{\circ} \mathrm{N}, 122^{\circ} \mathrm{W}$ obtained from Pacific Fisheries Environmental Laboratory (www.pfeg.noaa.gov/products/PFEL)

welling season (December to February), as defined by monthly upwelling indices (Fig. 3).

We calculated a measure of home range for each tagged fish in the following manner. For each hour that a fish was present in the array, it was assigned 1 or more locations, based on the receiver(s) that recorded signals from the tagged fish. The number of hours detected at each receiver location was tallied for each fish. Receiver locations that ranked in the 90th percentile of the total hours that a fish was recorded during time at liberty were used to calculate the home range of that fish. In ArcGIS, a polygon of best fit was drawn around these receiver locations, using the receiver detection radius of $150 \mathrm{~m}$. The area encompassing home range for each fish was then calculated using the ArcGIS spatial analyst extension, XToolsPro.

\section{RESULTS}

\section{Fishing and tagging}

A total of 23 small adult black rockfish was captured, tagged, and released in the study area between August 2006 and July 2007 (Table 1). Total length ( $\mathrm{TL}_{\text {; }}$ mean $\pm \mathrm{SE}$ ) of the 23 black rockfish was $32.7 \pm 0.7 \mathrm{~cm}$. Of the 23 black rockfish implanted with transmitters, 13 were females (TL $33.7 \pm 1.0 \mathrm{~cm}$ ) and 10 were males (TL $31.5 \pm 0.6 \mathrm{~cm}$ ) (Table 1). One fish (Tag 92) was only present in the study area for $2 \mathrm{~d}$, and another fish (Tag 81) only for $23 \mathrm{~d}$. There were no complications for these fish during surgical procedures, and both fish were observed swimming upon release, but were excluded from the majority of the analyses due to lack of data. The largest female black rockfish $(41 \mathrm{~cm}$; Tag 228$)$ released in this study was captured by a recreational angler on 30 June 
Table 1. Sebastes melanops. Tag numbers of small black rockfish released in Carmel Bay. Sex denoted as F (female) or $\mathrm{M}$ (male). Total days detected (Total days det.): number of days in which $\geq 2$ signals were recorded in a $24 \mathrm{~h}$ period for an individual. Residence time (Res. time): total number of days detected for each fish divided by the total number of days available in the battery life of a transmitter. TL: total length

\begin{tabular}{|lccrrr|}
\hline $\begin{array}{l}\text { Tag } \\
\text { no. }\end{array}$ & $\begin{array}{c}\text { TL } \\
(\mathrm{cm})\end{array}$ & Sex & $\begin{array}{c}\text { Release } \\
\text { date }\end{array}$ & $\begin{array}{c}\text { Total } \\
\text { days det. }\end{array}$ & $\begin{array}{r}\text { Res. time } \\
\text { (\% of } \text { d })\end{array}$ \\
\hline 78 & 31.5 & F & 28 Sep 2006 & 88 & 21.2 \\
80 & 35.0 & F & 5 Oct 2006 & 366 & 82.2 \\
81 & 33.0 & M & 22 Aug 2006 & 23 & 5.2 \\
82 & 34.0 & F & 29 Aug 2006 & 369 & 82.9 \\
83 & 33.0 & F & 3 Oct 2006 & 336 & 81.0 \\
84 & 32.0 & M & 5 Oct 2006 & 427 & 96.0 \\
85 & 30.0 & F & 28 Aug 2006 & 391 & 88.7 \\
86 & 38.0 & F & 3 Oct 2006 & 115 & 27.7 \\
87 & 29.5 & F & 5 Oct 2006 & 382 & 85.8 \\
88 & 33.5 & F & 11 Sep 2006 & 70 & 15.7 \\
89 & 36.5 & F & 4 Sep 2006 & 445 & 100.0 \\
90 & 34.5 & M & 1 Sep 2006 & 433 & 97.3 \\
91 & 32.0 & M & 7 Oct 2006 & 100 & 25.6 \\
92 & 29.0 & M & 9 Oct 2006 & 2 & 0.4 \\
93 & 30.0 & M & 11 Oct 2006 & 372 & 83.6 \\
94 & 35.0 & F & 11 Oct 2006 & 409 & 91.9 \\
95 & 32.0 & M & 9 Oct 2006 & 445 & 100.0 \\
227 & 30.5 & F & 11 Oct 2006 & 445 & 100.0 \\
228 & 41.5 & F & 15 Oct 2006 & 216 & 86.4 \\
229 & 29.0 & F & 15 Oct 2006 & 423 & 95.1 \\
4054 & 29.5 & M & 20 Jun 2007 & 53 & 10.2 \\
4058 & 29.0 & M & 20 Jun 2007 & 168 & 32.3 \\
4060 & 34.0 & M & 7 Jun 2007 & 181 & 34.8 \\
& & & & & \\
\hline
\end{tabular}

2007, after 198 d at liberty, near the Pinnacles SMR, close to the site where it was originally released.

\section{Residence times}

Residence times of small adult black rockfish in the study area ranged from $<1$ to $100 \%$ ( 2 to $445 \mathrm{~d}$ ) of the expected battery life of transmitters (Fig. 4). Residence time (mean $\pm \mathrm{SE}$ ) of all fish was $272.0 \pm 33.0 \mathrm{~d}$. We could detect no differences between residence times of female and male fish in a 2-sample $t$-test $(\mathrm{p}=$ 0.483 ). Of the 23 fish released, 14 were highly residential, i.e. were detected for $>75 \%$ of the days during the transmitter battery life of each tag. Of these 14 small adult black rockfish, 8 fish were detected in the receiver array between 75 and $95 \%$ of the days of transmitter battery life (i.e. detected in the array for 11 to $14 \mathrm{mo}$ ), and 6 fish were detected for $>95 \%$ of the days of transmitter battery life $(>14$ mo in the array). The remaining 9 small adult black rockfish were present in the study area for a mean of $34.8 \%$ of the days of transmitter battery life or $<6$ mo before permanent departure. After the study, we were notified by other researchers that signals from 4 of these fish were detected on receiver arrays north of the study area. Signals from Tag 83 were detected on 7 December 2007 on a receiver located near Año Nuevo Island, California, $52 \mathrm{~km}$ north of the study area, $3 \mathrm{~d}$ after it last recorded in our study area. Sim-

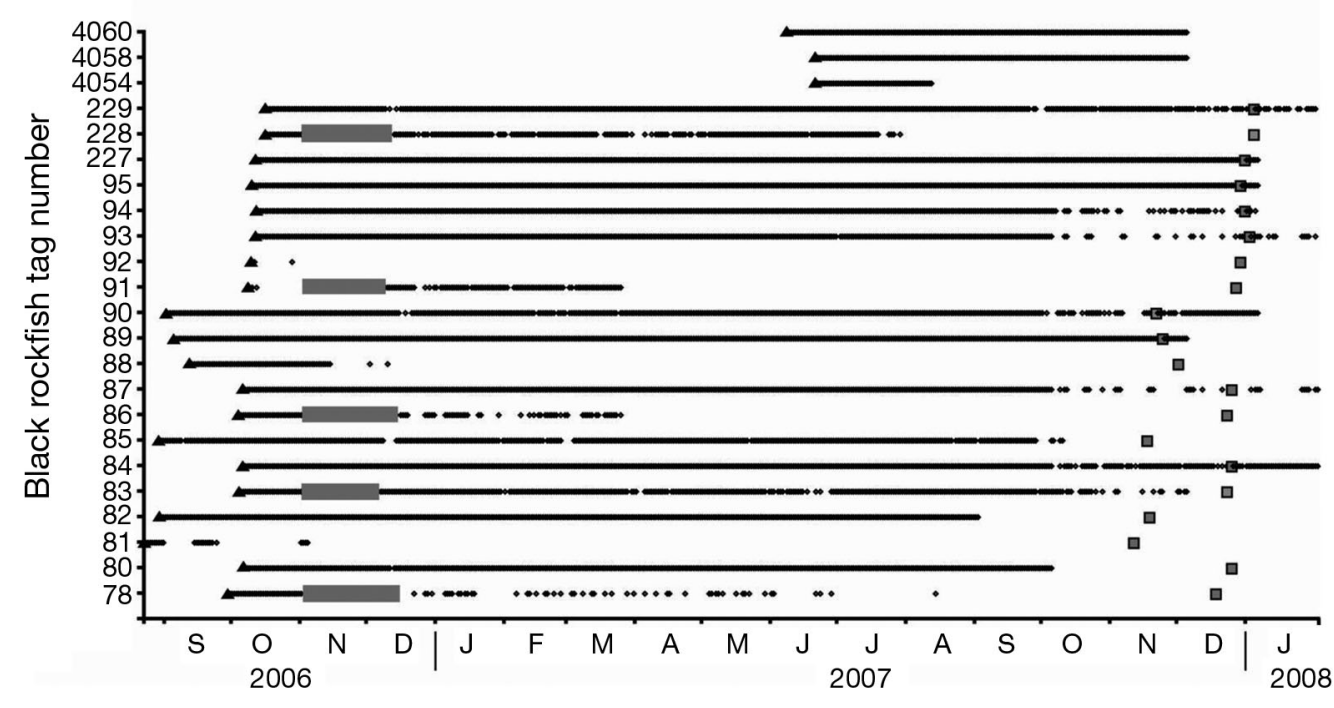

Fig. 4. Sebastes melanops. Residence times of small adult black rockfish as indicated by presence or absence in Carmel Bay. Tag number of each fish is listed on the $y$-axis. $\bullet$ : detection of signals from a tagged fish; $\wedge$ : date of tag and release of each fish; $\mathbf{\square}$ : projected battery life of tags (not indicated for tagged fish 4054, 4058, and 4060 as batteries expired after the study end); grey bars: time periods during which a receiver that was within the home range of a tagged fish was missing from the array 
ilarly, signals from 2 other tagged fish were recorded $186 \mathrm{~km}$ north of the study area (off Point Reyes, California); 7 and $4 \mathrm{~d}$, respectively, after they were last detected in the study area (4 December 2007 and 5 January 2008). Also, a single detection for Tag 227 was recorded on a receiver located $>1000 \mathrm{~km}$ north of our study area, near Neah Bay, Washington, on 21 June 2010. This tagged fish was last detected in Carmel Bay on 5 January 2008.

\begin{abstract}
Absences
Of the 23 tagged black rockfish, 7 individuals were detected every day during time at liberty. Of the 16 fish that did exhibit absences from the study area, 7 were absent $<7 \%$ and 4 were absent $<15 \%$ of the total time at liberty. The remaining 5 individuals had longer absences (26 to $84 \%$ ) of total time at liberty. The number of absences (mean \pm SE) from the receiver array for small adult black rockfish was $9.5 \pm$ 2.0. Duration (mean $\pm \mathrm{SE}$ ) of absences was $2.9 \pm 0.2 \mathrm{~d}$ for all fish combined, $2.8 \pm 0.3 \mathrm{~d}$ for females and $3.6 \pm$ $0.7 \mathrm{~d}$ for males. We could detect no differences between the duration of absences for males and females in a 2 -sample $t$-test $(p=0.548)$. We could detect no synchronous absences and returns from the study area among fish, although, for 7 individuals, the frequency and/or length of departures from the study area increased in the fall and winter (September to December 2007; Fig. 4).
\end{abstract}

\section{Diel movements}

The number of signal detections of small adult black rockfish in the study area during the night was significantly greater than during the day for the entire year (Pearson's chi-squared $=29.867$; $\mathrm{p}<$

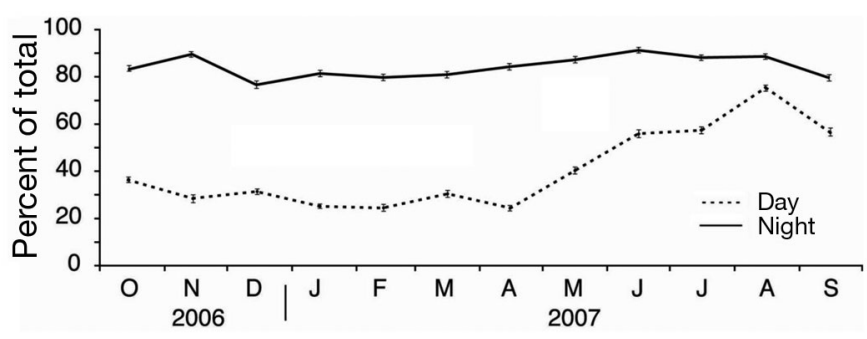

Fig. 5. Sebastes melanops. Monthly percentages of hours (mean $\pm \mathrm{SE}$ ) that black rockfish were present in the study area during the day ( $1 \mathrm{~h}$ after sunrise till $1 \mathrm{~h}$ before sunset). and night ( $1 \mathrm{~h}$ after sunset till $1 \mathrm{~h}$ before sunrise)
0.001), and for both the high and low upwelling seasons (April to June, Pearson's chi-squared $=21.001$; $\mathrm{p}=0.004$; December to February, Pearson's chisquared $=21.019 ; \mathrm{p}=0.007$ ). The annual percentage of hours (mean $\pm \mathrm{SE}$ ) tagged fish were detected was $74.6 \pm 0.04 \%$ of the night hours and $41.8 \pm 0.04 \%$ of the day hours. The monthly mean percentage of hours in which tagged fish were detected at night was relatively constant (between 77 and 89\%) throughout the year; however, the mean percentage of daytime hours in which all tagged fish were detected was lowest $(23.8 \pm 1.1 \%)$ in April 2007. This coincided with the peak of mean monthly upwelling (Fig. 3). In late May 2007, detections of small adult black rockfish began to increase during the day, peaking in August when the mean presence of all tagged fish was $75.0 \pm 1.2 \%$ of the day hours (Fig. 5).

\section{Vertical movements}

Water depths in the study area ranged from 10 to $20 \mathrm{~m}$. The annual depth (mean \pm SE) of all small adult black rockfish was $11.6 \pm 0.8 \mathrm{~m}$; mean depths of individuals ranged from 4.3 to $15.5 \mathrm{~m}$. Vertical movements of small adult black rockfish were highly variable. Depth changes from 5 to $10 \mathrm{~m}$ occurred frequently over short time intervals ( 5 to $20 \mathrm{~min}$ ). The difference between mean daily minimum and mean daily maximum depths for all fish during the study period was $6.4 \pm 0.1 \mathrm{~m}$. Mean day depths were significantly greater than mean night depths for 16 small black rockfish (Table 2) over the October 2006 to September 2007 period (paired $t$-test; $\mathrm{p}=0.026$ ).

\section{Environmental correlations}

Cross correlation analyses using data from a 1 yr period indicated that depth anomalies of tagged black rockfish were positively correlated with upwelling indices $(p<0.001)$ and the square of wave heights $(p=0.045)$ with a lag of $1 \mathrm{~d}$. When evaluated with respect to the months with the highest mean monthly upwelling indices (April to June), depth anomalies were positively correlated with atmospheric pressure, wind speed, the square of wave height, and the upwelling index, all with lags of 1 to 3 d (Table 3). Although cross correlation analyses showed a negative correlation between the upwelling index and water temperature $(p=0.028)$ with a lag of 1 d over 1 yr period, we could detect no significant relationships $(\mathrm{p}>0.05)$ between depth anom- 
alies and water temperature or the difference in water temperatures between 16 and $34 \mathrm{~m}$. However, when we plotted mean daily temperatures, it was apparent that tagged fish were deeper from midFebruary through mid-June when mean daily temperatures were low (Fig. 6). Tagged fish were significantly deeper in these months than at other times of the year $(2$-sample t-test; $\mathrm{p}<0.001)$. Cross correlation analyses of depth anomalies and environmental vari-

Table 2. Sebastes melanops. Mean day and night depths for small adult black rockfish over a 1 yr period (1 October 2006 to 30 September 2007). Mean day (night) depth (m) is the mean annual day (night) depth for each individual black rockfish. Day depth > night depth (\% of d) is the percentage of days in the year in which the mean day depth of a tagged fish was greater than the mean night depth of that fish on a particular date

\begin{tabular}{|c|c|c|c|}
\hline \multirow{2}{*}{$\begin{array}{l}\text { Tag } \\
\text { no. }\end{array}$} & \multicolumn{2}{|c|}{ Mean depth (m) } & \multirow{2}{*}{$\begin{array}{c}\text { Day depth > night } \\
\text { depth }(\% \text { of d) }\end{array}$} \\
\hline & Day & Night & \\
\hline 78 & 14.9 & 13.9 & 61.4 \\
\hline 80 & 11.1 & 10.6 & 44.4 \\
\hline 83 & 16.8 & 14.6 & 73.2 \\
\hline 84 & 16.6 & 15.5 & 81.6 \\
\hline 85 & 4.8 & 4.3 & 61.1 \\
\hline 86 & 14.7 & 14.5 & 56.9 \\
\hline 87 & 14.6 & 15.0 & 26.8 \\
\hline 88 & 7.6 & 7.1 & 45.3 \\
\hline 89 & 10.1 & 10.5 & 29.8 \\
\hline 90 & 11.6 & 11.6 & 40.4 \\
\hline 93 & 14.2 & 15.0 & 33.5 \\
\hline 94 & 11.8 & 11.0 & 56.0 \\
\hline 95 & 10.1 & 7.8 & 77.8 \\
\hline 227 & 15.2 & 15.2 & 49.0 \\
\hline 228 & 11.5 & 10.2 & 51.4 \\
\hline 229 & 12.4 & 12.5 & 55.6 \\
\hline
\end{tabular}

Table 3. Sebastes melanops. Lag in days, correlation, and p-values associated with cross correlations among selected environmental variables and the depth anomalies of tagged black rockfish for 1 April 2007 to 30 June 2007. Positive correlations indicate that tagged fish move deeper when atmospheric pressure, wind speed, upwelling index, or wave height increases (NS $=$ not significant, $\mathrm{p}>0.05$ )

\begin{tabular}{|lccc|}
\hline & Lag $(\mathrm{d})$ & Correlation & $\mathrm{p}$ \\
\hline Atmospheric pressure & 2 & 0.236 & 0.026 \\
Wind speed & 3 & 0.227 & 0.033 \\
Upwelling index & 1 & 0.309 & 0.003 \\
Wave height (squared) & 1 & 0.274 & 0.009 \\
Tidal stage & & & $\mathrm{NS}$ \\
Temperature & & & $\mathrm{NS}$ \\
\hline
\end{tabular}

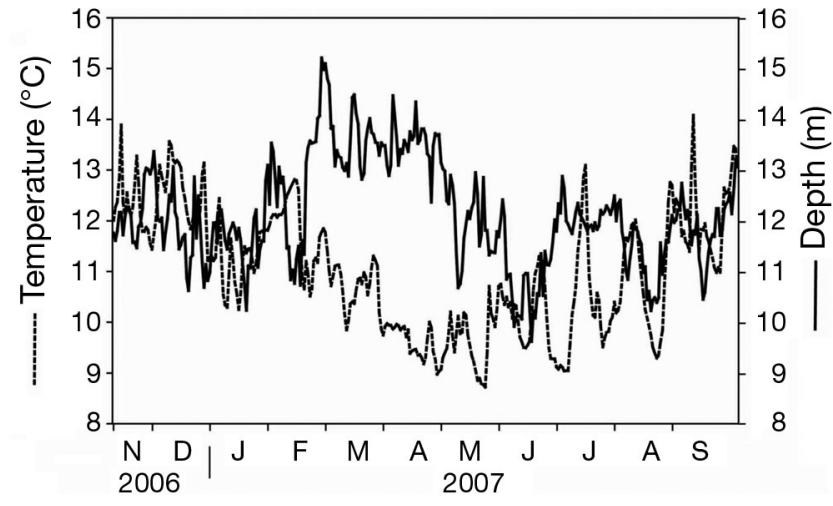

Fig. 6. Sebastes melanops. Mean daily water temperatures $\left({ }^{\circ} \mathrm{C}\right)$ at $16 \mathrm{~m}$ depth and mean daily depth anomalies $(\mathrm{m})$ for black rockfish during the period 10 November 2006 through 30 September 2007

ables conducted for the months with the lowest mean monthly upwelling indices (December to February) revealed no relationships at the $95 \%$ level of significance, but upwelling and the square of wave height were both positively correlated to depth anomalies with $\mathrm{p}=0.080$. We could detect no significant relationships between depths and tidal stages.

\section{Home range}

Home ranges of small adult black rockfish were centered near the original site of release for each fish (Fig. 7). Home range areas for small adult black rockfish varied from 0.07 to $0.56 \mathrm{~km}^{2}$. Home range area $\left(\right.$ mean $\pm \mathrm{SE}$ ) was $0.25 \pm 0.04 \mathrm{~km}^{2}$, and a mean of $2.6 \pm$ 0.3 receiver locations was used in these home range estimations. Mean home range area for the 13 female fish was $0.28 \pm 0.05 \mathrm{~km}^{2}$ and was $0.20 \pm 0.05 \mathrm{~km}^{2}$ for the 8 male fish. We detected no significant differences in mean home range area between males and females (2-sample $t$-test; $\mathrm{p}=0.364)$, and regression analysis revealed no significant relationship between total length and home range areas by sex, nor for all fish combined $(p=0.100)$.

\section{DISCUSSION}

\section{Residence time and absences from the array}

The site fidelity of an individual fish to a given area is related to many factors, including life-history characteristics, ontogeny, environmental variability, and resource availability. Acoustic telemetry studies have 


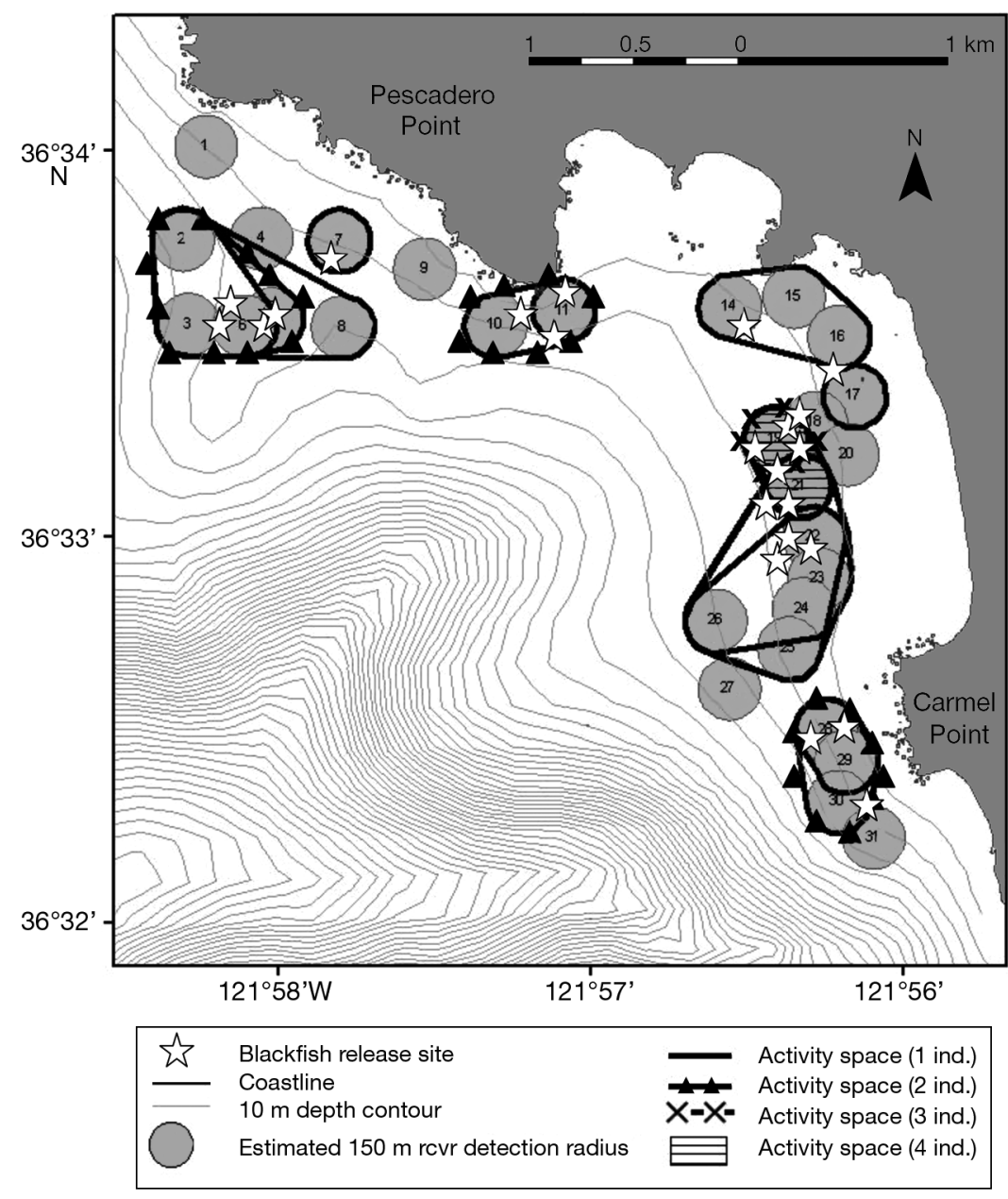

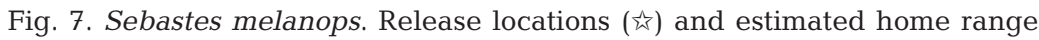
areas for tagged black rockfish in the study area. Polygons represent the home range of a tagged fish based on the receiver locations where the fish was recorded during $90 \%$ of the hours at liberty. Polygons: solid black outline = home range used by 1 individual; with triangles = home range used by 2 individuals; with $\times=$ home range used by 3 individuals; filled with stripes $=$ area used by 4 individuals; numbered grey circles: receiver locations with estimated detection area

fish in our study migrated north; signals from fish carrying Tag IDs 83, 89, 94, and 227 were recorded on receiver arrays maintained by other researchers north of our study site. These detections of our tagged fish at distances north of the study area corroborate information about longdistance northward movements presented in several unpublished tagrecapture reports (Coombs 1979, DeMott 1983, Starr \& Green 2007).

The short residence times documented for the 9 small adult black rockfish in our study could be the result of handling mortality, tag malfunction, fishing mortality, natural mortality, or undocumented emigration from the study area. Mortality due to tagging complications would be most likely to occur in the first week after release (Starr et al. 2000, Lowe et al. 2009), and only 1 fish in our study (Tag 92) was detected for $<2$ d. We cannot discount handling mortality or predation for this individual, but it seems unlikely for others. All tags were tested before deployment, and other acoustic studies have shown that the Vemco tags we used have a low $(<1 \%)$ failure rate (Voegeli \& Starr 2000). At least 1 tagged individual was a known fishing mortality, and it is possible that others were caught and we were not notified. However, we estimated expected mortality using a survivorship equation (Wilson \& Bossert 1971) and determined that the natural and fishing mortality rates would each need

shown that several nearshore rockfishes exhibit high site fidelity (Matthews 1990, Jorgensen et al. 2006, Parker et al. 2007, Lowe et al. 2009). In those studies, a few tagged fish departed the study area within a few months of release, but the departures were considered to be outliers rather than indicative of normal behavior. In our study, many of the tagged small adult black rockfish Sebastes melanops exhibited residence times that were similar to those of other nearshore rockfishes, however, the tagged black rockfish in our study differed in that more than onethird of the fish displayed short residence times $(<6 \mathrm{mo})$ and moved out of the study region. At least 4 to have been 3 times greater than rates used in stock assessments to account for the reduction in tagged fish recorded. There is no reason to expect fishing and natural mortality rates to be that high in the MPAs we studied. The evidence of northward migrations documented for the 4 small adult black rockfish that were recorded on other acoustic receiver arrays indicate that emigration is a likely hypothesis for the short residence times exhibited by the tagged fish that were detected in the study area $<6$ mo after release.

If our assumption of emigration is correct, we suggest 2 hypotheses why small adult black rockfish left 
Carmel Bay. (1) Movements were triggered by major storm events. Fish emigration has been correlated with the onset of winter storm activity in temperate environments for juvenile rockfish (Johnson et al. 2001) and summer flounder (Sackett et al. 2007). In tropical environments, Ingram \& Patterson (2001) showed that movements were larger and more frequent for fish at liberty during tropical storms than periods without storms, and Heupel et al. (2003) described greater movements of small sharks immediately prior to arrival of a tropical storm. In our study in Carmel Bay, the last detections of 10 fish coincided with major storm events. Four small adult black rockfish were last detected during a storm on 4 December 2007, and 4 others, on the storm of 5 January 2008. An additional 2 fish were last detected a few days before a major storm on 27 March 2007. Signals from 4 of the 10 fish that were last detected during storms were recorded on receivers located at the very north end of the study area, despite the fact that these fish had previously exhibited strong site fidelity to a different area of the array. On all occasions, storms were characterized by sustained swells of $>4.5 \mathrm{~m}$ over a $24 \mathrm{~h}$ period, with recorded maximum wave heights of up to $10 \mathrm{~m}$. Cross correlation analyses indicated that tagged fish moved deeper with increasing wave heights. The high wave heights associated with large winter storms may have led to movements to deeper waters and then to a northward migration. (2) Emigration from the study area was related to an ontogenetic shift in habitat use. A common trait observed in rockfishes is the use of shallow water habitats as juveniles and a transition to deeper water habitats as adults (Boehlert \& Yoklavich 1983, Love et al. 1991). Adult fish in some reef-associated species have greater site fidelity and increased homing ability than juvenile fish (Hallacher \& Roberts 1985), and Parker et al. (2008) speculated that adult black rockfish maintain small home ranges by making frequent descents to the bottom for visual spatial reference. However, if a major storm caused tagged black rockfish to lose visual contact with the bottom, the small adult black rockfish in Carmel Bay may not have the same navigation ability of older conspecifics to return to a home area. The greater residence times for black rockfish documented by Parker et al. (2007) may be attributed to differences in the size or maturity of the tagged black rockfish in their study. Greater emigration rates for small adult black rockfish in Carmel Bay may be representative of ontogenetic changes in movement patterns as these fish transit to maturity.
Regardless of the cause of emigration of small adult black rockfish from the study area, our data indicate that fish that left the study area moved northward in winter. We do not know what the mechanism is for this movement, but note that it occurred in winter, when the Davidson current becomes shallower and moves north at higher speeds (Hickey 1979, Huyer et al. 1989). One possibility is that, as black rockfish lose visual contact with the bottom, they are carried northward by the Davidson current. Another possibility, however, is that small black rockfish are moving in search of prey. Dorman et al. (2011) modeled winter ocean conditions to describe how krill Euphausia pacifica are advected poleward in the winter. It is possible that small adult black rockfish move northward to stay in water masses that contain more food than is available in kelp beds in winter.

\section{Diel movements}

Differences in habitat use between day and night periods have been documented in many fish species. In coral reef fishes, crepuscular 'commutes' between distinct day and night habitats are common (Mazeroll \& Montgomery 1995, Holland et al. 1996, Meyer et al. 2007). Diel vertical movements have been noted for juvenile black rockfish (Leaman 1976, Carr 1991), and directed crepuscular and nocturnal movements have been reported in this region for tagged rockfishes (Starr et al. 2002, Jorgensen et al. 2006, Tolimieri et al. 2009) and sharks (Carlisle \& Starr 2009, Dawson \& Starr 2009). In our study, small adult black rockfish in Carmel Bay exhibited repeated diurnal movement patterns: departing the study area in the morning crepuscular hours and remaining outside the study area during the next 10 to $12 \mathrm{~h}$ before returning to the study area in the evening.

Although small adult black rockfish moved outside of receiver reception range during the day, the change in depth use between day and night periods enabled us to determine the direction of movements. The deeper depths recorded during the day than at night are indicative of movement offshore during the day. Although depth data recorded during daytime were limited to time periods when fish were entering and exiting the array, an increase in mean depth was observed during the day for $>50 \%$ of all tagged individuals. These greater depths during the day indicate that small adult black rockfish in Carmel Bay moved to deeper waters outside the kelp forest during daytime, and returned to shallower depths inside the kelp forest at night. 


\section{Seasonal movements}

The seasonal movements that we observed for black rockfish are consistent with the hypothesis that movements of fishes may be driven by prey distribution (Hallacher \& Roberts 1985). A large portion (up to $73 \%$ ) of the black rockfish diet is composed of young-of-the-year (YOY) Sebastes spp. in the summer upwelling season (Hallacher \& Roberts 1985, Hobson et al. 2001), an important feeding time when rockfishes increase their fat reserves for winter (Guillemot et al. 1985). In our study, a reduction in home range to shallow kelp habitats by tagged small adult black rockfish coincided with typical peak settlement of YOY Sebastes spp. to the kelp forest (Miller \& Geibel 1973, Hallacher \& Roberts 1985, Hobson et al. 2001, Studebaker \& Mulligan 2008).

Hallacher \& Roberts (1985) observed that diets of black rockfish change seasonally, with a switch from fish to invertebrates during the non-upwelling season. This, along with the increase in the percentage of empty black rockfish stomachs, led them to speculate that food is a limiting resource for black rockfish during the non-upwelling season. In our study, diurnal movements out of the study area were greatest for small adult black rockfish in the winter and spring, and corresponded to the decrease in black rockfish densities observed by Hallacher \& Roberts (1985) in Carmel Bay kelp forests during the nonupwelling season.

\section{Vertical movements and environmental correlations}

Similar to the results reported by Parker et al. (2008), small adult black rockfish in Carmel Bay exhibited many different vertical movement patterns. Given the degree of vertical activity in black rockfish and the relatively weak behavioral coherence among black rockfish described in Parker et al. (2008), we did not attempt to categorize vertical movement behavior in the same way. Instead, we compared depth anomalies and environmental parameters, hypothesizing that over long periods of time, small adult black rockfish may be responding in the same way to certain environmental cues. The positive correlations observed between black rockfish depth anomalies and atmospheric pressure, wind speed, upwelling, and wave heights are examples of how wind stress and resulting upwelling, as well as low pressure storm systems, affect black rockfish and other nearshore species in the California current. The in- creased primary productivity associated with upwelling fronts results in increased zooplankton abundance; a primary prey source for rockfishes during strong upwelling events in central California (Hayward et al. 1999). Just as we hypothesized that small adult black rockfish in Carmel Bay maintain smaller home ranges in kelp habitats in the summer during the peak YOY rockfish settlement, it is likely that during the winter and spring upwelling seasons, the distribution of locally abundant prey affects movements of small adult black rockfish (Ainley et al. 1993, Schwing et al. 2000).

Positive correlations between the depth distribution of small black rockfish and barometric pressure and wave heights may have been a response to seasonal environmental conditions such as increased storm activity. For example, blue rockfish move to deeper waters to avoid winter storm turbulence (Miller \& Geibel 1973). Hallacher \& Roberts (1985) and Parker et al. (2008) reported that black rockfish were significantly closer to the bottom in winter. Another possible reason for the deeper depths of black rockfish during the winter and spring is that black rockfish are avoiding increased water turbulence from wave action during seasonal periods typified by higher storm activity.

Although cross correlation analyses indicated no significant relationship between depth anomalies and water temperature over the entire year, tagged fish in our study were significantly deeper from mid-February though mid-June, when water temperatures were at an annual minimum. Many fish species respond to changes in ambient water temperature by changing depths (e.g. Shrode et al. 1982). The coldest ambient water temperatures in Carmel Bay occurred from March through July 2007, with the lowest mean monthly temperature occurring in April. It is possible, however, that this depth pattern is not entirely driven by water temperature. Hallacher \& Roberts (1985) reported that black rockfish were significantly closer to the bottom during fall and winter, during which time invertebrates comprised a large proportion of black rockfish diets. If black rockfish are relying mostly on invertebrates for food during the non-upwelling season, changes in seasonal depth distributions of small adult black rockfish observed in the study area may be related to prey depth distributions.

\section{Implications for management}

Often, for species that demonstrate high rates of residency, the small percentage of fish that move 
long distances are considered anomalies and ignored in management. Data from this study, and from a tagrecapture study at Duxbury Reef near Bolinas, California (Starr \& Green 2007), however, indicate that black rockfish exhibit a bimodal distribution in movements, and between 10 and $40 \%$ of the small black rockfish have low site fidelity, and may move long distances, indicating that black rockfish should not be characterized as displaying limited movements.

Small MPAs may be an effective fisheries management technique, if the management goal is to protect the proportion of a population that has strong site fidelity or to facilitate spillover of individuals. The large adult black rockfish tagged in the Parker et al. (2007) study, and many of the small adult black rockfish in our study, had small home ranges during the time they were present, a good characteristic for MPA protection. However, more than one-third of the small adult black rockfish we tagged exhibited low fidelity to the study area. Thus, although MPAs may provide protection for adult black rockfish that exhibit strong site fidelity, not all life stages of black rockfish would be protected by small reserves.

Acknowledgements. The authors thank all volunteers for their help with field work for this project, but particularly Ashley Greenley. Dr. Larry Breaker provided help with cross correlation analyses and interpretation. We thank Pete Klimley and 2 anonymous reviewers for improving the manuscript. Funding for this study was provided by the California Sea Grant College Program, the Packard Foundation, Moss Landing Marine Laboratories, and the Myers Oceanographic and Marine Biological Trust. This study was conducted under the approval of the San Francisco State University Human and Animal Subjects Protocol No. A7-006 and San Jose State University Protocol No. 824.

\section{LITERATURE CITED}

Ainley DG, Sydeman WJ, Parrish RH, Lenarz WH (1993) Oceanic factors influencing distribution of young rockfish (Sebastes) in central California: a predator's perspective. CCOFI Rep 34:133-139

Boehlert GW, Yoklavich MM (1983) Effects of temperature, ration, and fish size on growth of juvenile black rockfish, Sebastes melanops. Environ Biol Fishes 8:17-28

Botsford LW, Brumbaugh DR, Grimes C, Kellner JB and others (2008) Connectivity, sustainability and yield: bridging the gap between conventional fisheries management and marine protected areas. Rev Fish Biol Fish 19:69-95

> Carlisle AB, Starr RM (2009) Habitat use, residency, and seasonal distribution of female leopard sharks Triakis semifasciata in Elkhorn Slough, California. Mar Ecol Prog Ser 380:213-228

Carr MH (1991) Habitat selection and recruitment of an assemblage of temperate zone reef fishes. J Exp Mar Biol Ecol 146:113-137

Coombs CI (1979) Reef fishes near Depoe Bay, Oregon: movement and the recreational fishery. MS thesis, Oregon State University, Corvallis

Culver BN (1986) Results from tagging black rockfish (Sebastes melanops) off the Washington and northern Oregon coast. In: Proceedings of the international rockfish symposium, Anchorage, Alaska. Alaska Sea Grant Report no. 87.2, Alaska Sea Grant College Program, University of Alaska, Fairbanks, AK, p 231-240

> Dawson CL, Starr RM (2009) Movements of subadult prickly sharks Echinorhinus cookei in the Monterey Canyon. Mar Ecol Prog Ser 386:253-262

DeMott GE (1983) Movement of tagged lingcod and rockfishes off Depoe Bay, Oregon. MS thesis, Oregon State University, Corvallis

Dorman JG, Powell TM, Sydeman WJ, Bograd SJ (2011) Advection and starvation cause krill (Euphausia pacifica) decreases in 2005 northern California coastal populations: implications from a model study. Geophys Res Lett 38:L04605 doi:10.1029/2010GL046245

Greenley AP (2009) Movements of lingcod, Ophiodon elongatus tagged in Carmel Bay, California. MS thesis, Moss Landing Marine Laboratories, Moss Landing, CA

Guillemot PJ, Larson RJ, Lenarz H (1985) Seasonal cycles of fat and gonad volume in five species of northern California rockfish (Scorpaenidae, Sebastes). Fish Bull 83: 299-311

Hallacher LE, Roberts DA (1985) Differential utilization of space and food by the inshore rockfishes (Scorpaenidae: Sebastes) of Carmel Bay, California. Environ Biol Fish 12: 91-110

Halpern BS, Warner RR (2002) Marine reserves have rapid and lasting effects. Ecol Lett 5:361-366

Hayward TL, Baumgartner TR, Checkley UM, Durazo R and others (1999) The state of the California Current, 1998-1999: transition to cool-water conditions. Calif Coop Ocean Fish Invest Rep 40:29-62

> Heupel MR, Simpfendorfer CA, Heuter RE (2003) Running before the storm: blacktip sharks respond to falling barometric pressure associated with tropical storm Gabrielle. J Fish Biol 63:1357-1363

Hickey BM (1979) The California current system - hypotheses and facts. Prog Oceanogr 8:191-279

Hobson EJ, Chess JR, Howard D (2001) Interannual variation in predation on first-year Sebastes spp. by three northern California predators. Fish Bull 99:292-302

Holland KN, Lowe CG, Wetherbee BM (1996) Movements and dispersal patterns of blue trevally (Caranx melampygus) in a fisheries conservation zone. Fish Res 25:279292

Huyer AP, Kosro M, Lentz S, Beardsley RC (1989) Poleward flows in the California Current System. In: Neshyba SJ, Mooers CK, Smith RL, Barber RT (eds) Poleward flows along eastern ocean boundaries. Coastal and estuarine studies, Vol 34. Springer, Heidelberg

Ingram GW, Patterson WF (2001) Movement patterns of red snapper (Lutjanus campechanus), greater amberjack (Seriola dumerili), and gray triggerfish (Balistes capriscus) in the Gulf of Mexico and the utility of marine reserves as management tools. Proc Gulf Caribb Fish Inst 52:686-699

Johnson KA, Yoklavich MM, Cailliet GM (2001) Recruitment of three species of juvenile rockfish (Sebastes spp.) 
on soft benthic habitat in Monterey Bay, California. Calif Coop Ocean Fish Invest Rep 42:153-166

Jorgensen SJ, Kaplan DM, Klimley AP, Morgan SG, O'Farrell MR, Botsford LW (2006) Limited movement in blue rockfish Sebastes mystinus: internal structure of home range. Mar Ecol Prog Ser 327:157-170

Katz RW (1988) Use of cross correlations in the search for teleconnetions. J Climatol 8:241-253

Leaman B (1976) The association between the black rockfish (Sebastes melanops Girard) and beds of the giant kelp (Macrocystis intergrifolia Bory) in Barkley Sound, British Columbia. PhD dissertation, University of British Columbia, Vancouver

Love MS, Carr MC, Haldorson LJ (1991) The ecology of substrate-associated juveniles of the genus Sebastes. Environ Biol Fishes 30:225-243

Lowe CG, Anthony KM, Jarvis ET, Bellquist LF, Love MS (2009) Site fidelity and movement patterns of groundfish associated with offshore petroleum platforms in the Santa Barbara Channel. Mar Coast Fish Dyn Manag Ecosystem Sci 1:71-89

Mason J (1998) Declining rockfish lengths in the Monterey Bay, California, recreational fishery in 1959-94. Mar Fish Rev 60:15-28

Mathews SB, Barker MW (1983) Movements of rockfish (Sebastes) tagged in northern Puget Sound, Washington. US Nat Mar Fish Ser Fish Bull 81:916-922

Matthews KR (1990) A telemetric study of the home ranges and homing routes of copper and quillback rockfishes on shallow rocky reefs. Can J Zool 68:2243-2250

Mazeroll AI, Montgomery WL (1995) Structure and organization of local migrations in brown surgeonfish (Acanthurus nigrofuscus). Ethology 99:89-106

Meyer CG, Holland KN, Papastamatiou YP (2007) Seasonal and diel movements of giant trevally Caranx ignobilis at remote Hawaiian atolls: implications for the design of Marine Protected Areas. Mar Ecol Prog Ser 333:13-25

> Micheli F, Halpern BS, Botsford LW, Warner RR (2004) Trajectories and correlates of community change in no-take marine reserves. Ecol Appl 14:1709-1723

Miller DJ, Geibel JJ (1973) Summary of blue rockfish and lingcod life histories; a reef ecology study and giant kelp Macrocystis pyrifera experiments in Monterey Bay, California. Fish Bull Calif Dep Fish Game 158:3-137

O'Farrell MR, Botsford LW (2006) Estimating the status of nearshore rockfish (Sebastes spp.) with length frequency data. Ecol Appl 16:977-986

Parker SJ, Rankin PS, Olson JM, Hannah RW (2007) Movement patterns of black rockfish (Sebastes melanops) in Oregon coastal waters. In: Heifietz J, Dilusino J, Gharett AJ, Love MS, O'Connell VM, Stanley RD (eds) Biology, assessment, and management of North Pacific rockfishes. Alaska Sea Grant Report AK-SG-07-01, Alaska Sea Grant College Program, University of Alaska, Fairbanks, AK, p 39-57

Editorial responsibility: Steven Morgan, Bodega Bay, California, USA
Parker SJ, Rankin PS, Olson JM, Hannah RW, Malvitch JS (2008) Patterns in vertical movements of black rockfish Sebastes melanops. Aquat Biol 2:57-65

$>$ Russ GR, Stockwell B, Alcala AC (2005) Inferring versus measuring rates of recovery in no-take marine reserves. Mar Ecol Prog Ser 292:1-12

Sackett DK, Able KW, Grothues TM (2007) Dynamics of summer flounder, Paralicthys dentatus, seasonal migrations based on ultrasonic telemetry. Estuar Coast Shelf Sci 74:119-130

Schwing FB, Moore CS, Ralston S, Sakuma KM (2000) Record coastal upwelling in the California Current in 1999. CCOFI Rep 41:148-161

Shrode J, Zerba K, Stephens J (1982) Ecological significance of temperature tolerance and preference of some inshore California fishes. Trans Am Fish Soc 111:45-51

Starr RM, Green KM (2007) Species composition, relative abundance, and movements of important nearshore fish species along the North Central California coast. Final report, Pacific States Marine Fisheries Commission, Portland, OR

Starr RM, Heine JN, Johnson KA (2000) In situ techniques for tagging and tracking rockfishes. N Am J Fish Manage 20:597-609

Starr RM, Heine JN, Felton JM, Cailliet GM (2002) Movements of bocaccio (Sebastes paucispinis) and greenspotted (S. chlorostictus) rockfishes in a Monterey submarine canyon: implications for the design of marine reserves. Fish Bull 100:324-337

Starr RM, O'Connell V, Ralston S (2004) Movements of lingcod (Ophiodon elongatus) in southeast Alaska: potential for increased conservation and yield from marine reserves. Can J Fish Aquat Sci 61:1083-1094

Studebaker RS, Mulligan TJ (2008) Temporal variation and feeding ecology of juvenile rockfish (Sebastes) in rocky intertidal tidepools of northern California, with emphasis on Sebastes melanops Girard. J Fish Biol 72:1393-1405

> Tolimieri N, Andrews K, Williams G, Katz S, Levin PS (2009) Home range size and patterns of space use by lingcod, copper rockfish and quillback rockfish in relation to diel and tidal cycles. Mar Ecol Prog Ser 380:229-243

Voegeli FA, Starr RM (2000) Automated monitoring of fish movements and data telemetry from acoustic tags. In: Eiler JH, Alcorn DJ, Neuman MR (eds) Biotelemetry 15: Proc 15th Int Symp Biotelemetry, Juneau, Alaska USA. International Society on Biotelemetry, Wageningen, p 202-211

White C, Kendall BE, Gaines S, Siegel DA, Costello C (2008) Marine reserve effects on fishery profit. Ecol Lett 11: 370-379

Wilson EO, Bossert WH (1971) A primer of population biology. Sinauer, Stamford, CT

Wyllie Echeverria T (1987) Thirty-four species of California rockfishes: maturity and seasonality of reproduction. Fish Bull 85:229-250

Submitted: July 12, 2010; Accepted: June 11, 2011

Proofs received from author(s): August 22, 2011 